\title{
Characterization of the 6-aminohexanoate-dimer hydrolase from Pseudomonas sp. NK87
}

\author{
Kazuo Kanagawa, Mayumi Oishi, Seiji Negoro, ${ }^{*}$ Itaru Urabe and Hirosuke Okada $\dagger$ \\ Department of Biotechnology, Osaka University, 2-1 Yamada-oka, Suita-shi, Osaka 565, Japan
}

(Received 27 April 1992; revised 20 July 1992; accepted 1 December 1992)

\begin{abstract}
The DNA base sequence of the Pseudomonas sp. NK87 gene (P-nylB) for 6-aminohexanoate-dimer hydrolase (PEII), a xenobiotic-compound-degrading enzyme, was determined. It has an open reading frame of $1188 \mathrm{bp}$, initiated by ATG and terminated by TAG, and coding for 396 amino acids. The base sequence of the open reading frame has $53 \%$ sequence similarity to that of the gene for the same enzyme of Flavobacterium sp. KI72 (F-nylB) and $35 \%$ sequence similarity with respect to the deduced amino acid sequence. The P-EII enzyme was purified from an Escherichia coli clone in which the P-EII gene was highly expressed. The P-EII enzyme was inhibited by a serine protease inhibitor, diisopropyl fluorophosphate, as was the F-EII enzyme. Double reciprocal plots obtained from various concentrations of 6-aminohexanoate-dimer indicated that the $k_{\text {cat }}$ value of the P-EII enzyme $\left(9 \cdot 2 \mathrm{~s}^{-1}\right)$ was approximately half that of the F-EII enzyme $\left(19 \mathrm{~s}^{-1}\right)$, and the P-EII enzyme had higher affinity toward this substrate $\left(K_{\mathrm{m}}\right.$ for P-EII, $0.6 \mathrm{mM} ; K_{\mathrm{m}}$ for F-EII, $15 \mathrm{~mm}$ ). The P-EII enzyme had a temperature optimum of $48{ }^{\circ} \mathrm{C}$, and a pH optimum of 7.5. It is speculated that since the P-nylB and F-nylB genes are more diverged from each other than the corresponding nylA genes, the latter may have evolved more recently.
\end{abstract}

\section{Introduction}

Micro-organisms are believed to be highly adaptive toward environmental conditions. Such adaptability is implied from the observation that micro-organisms which metabolize various xenobiotic compounds can be easily isolated from nature (Hicks et al., 1990; Cork \& Krueger, 1991). We have isolated two bacterial strains, Flavobacterium sp. KI72 (Kinoshita et al., 1977) and Pseudomonas sp. NK87 (Kanagawa et al., 1989), which

*Author for correspondence. Tel. 06877 5111; fax 068762250.

† Present address: Department of Applied Microbial Technology, Kumamoto Institute of Technology, 4-22-1 Ikeda, Kumamoto 860, Japan.

\footnotetext{
Abbreviations: EI, 6-aminohexanoate-cyclic-dimer hydrolase; EII, 6aminohexanoate-dimer hydrolase; $n y l A$, EI gene; nylB, EII gene (the prefixes $\mathrm{F}$ - and $\mathrm{P}$ - denote the enzymes and genes from Flavobacterium and Pseudomonas, respectively); LB medium, Luria-Bertani medium; AL2, 3, 4 and 5, 6-aminohexanoate-dimer, -trimer, -tetramer and -pentamer; AC2, 6-aminohexanoate-cyclic dimer; Z-AL2 and 3, $\mathrm{N}$ carbobenzoxy-6-aminohexanoate-dimer and -trimer; DFP, diisopropyl fluorophosphate; TNBS, trinitrobenzene sulphonate.
}

The sequences reported in this paper have been submitted to GenBank and have been assigned the accession number D10678. can degrade 6-aminohexanoate-cyclic dimer (AC2), a by-product of the nylon- 6 industry. In both strains, 6-aminohexanoate-cyclic-dimer hydrolase (EI, EC 3.5.2.12) (Kinoshita et al., 1977) and, 6-aminohexanoate-dimer hydrolase (EII, EC 3.5.1.46) (Kinoshita et al., 1981) are responsible for the degradation of the cyclic dimer. In Flavobacterium sp. KI72 the EI gene (F-nylA) and the EII gene (F-nylB) are encoded on the same plasmid, pOAD2 (Negoro et al., 1980, 1983), while in Pseudomonas sp. NK87 the EI gene (P-nylA) and the EII gene (P-nylB) are encoded on different plasmids, pNAD2 and pNAD6, respectively (Kanagawa et al., 1989). These results suggest that gene transfer mediated by plasmids plays an important role in the distribution of the ability to degrade this new xenobiotic compound.

We have compared the sequences of F-nylA and P$n y l A$ genes and found that they show $99 \%$ similarity with respect to the DNA base sequence and the deduced amino acid sequence (Tsuchiya et al., 1989). This suggests that the nylA genes diverged only recently. Anti-F-EII serum does not cross-react with P-EII enzyme, whereas anti-F-EI serum reacts with P-EI. These results suggest that the $n y l B$ genes diverged earlier than the nylA genes. To obtain direct information about the evolutionary distance between the two EII enzymes, in this study we 
determined the DNA base sequence of the P-nylB gene and compared it with the sequence of the F-nylB gene reported previously (Okada et al., 1983). We also purified the P-EII enzyme from an Escherichia coli clone in which the P-nylB gene was highly expressed, and examined the basic characteristics of the enzyme.

\section{Methods}

Enzymes and chemicals. Restriction endonucleases (BamHI, EcoRI, EcoRV, HincII, HindIII, NruI, PvuII, PstI, RsaI, SalI, SmaI and SphI), T4 DNA ligase, DNA polymerase I (Klenow fragment), exonuclease III and mung bean nuclease were obtained from Toyobo Co. Other chemicals used were certified reagent grade and were purchased from Nacalai Tesque Co. (Kyoto). The 6-aminohexanoate-oligomer (AL2AL5), and its $N$-carbobenzoxy derivatives (Z-AL2, Z-AL3) were synthesized in our laboratory by the mixed anhydride method (Kinoshita et al., 1975). AC2 was purified by crystallization from hot water (Kinoshita et al., 1975). The following commercial dipeptides were used for the enzyme assay: L-Ala-Gly, L-Ala-L-Phe, L-Ala-L-Asp, L-Ala-L-Tyr, LAla-L-Ile, L-Ala-L-Thr, DL-Ala-DL-Asn, L-Ala-L-Pro, LAla-L-Ala, L-Ala-L-Trp, L-Ala-L-Glu, L-Ala-L-Lys, L-Ala-L-Met, GlyL-Ala, L-His-L-Ala, L-Val-L-Ala, L-Pro-L-Ala, L-Glu-L-Ala, L-Met-LAla, L-Phe-L-Ala, L-Trp-L-Ala, L-Tyr-L-Ala, L-Ser-L-Ala, L-His-Gly, LVal-Gly, L-Val-L-Phe, L-Leu-Gly, L-Phe-Gly, L-Asp-Gly, L-Tyr-Gly, L-Met-Gly, L-Lys-Gly, L-Lys-L-Ala, L-Lys-L-Asp, L-Lys-L-Phe, L-LysL-Lys，L-Lys-L-Leu，L-Lys-L-Val，L-Trp-Gly， L-Pro-Gly， L-Ser-Gly, L-Leu-L-Leu, L-Glu-L-Val (Sigma); DL-Ala-DL-Leu, Gly-DL-Leu (Nutritional Biochemicals); DL-Ala-Gly, Gly-Gly, L-Leu-L-Ala (Nacalai Tesque); Gly-L-Val, Gly-L-Phe, Gly-L-Pro, L-His-L-Leu (Protein Research Foundation); Gly-L-Leu, DL-Ala-L-Ala (Tokyo Kasei-Kogyo Co.); L-Leu-L-Tyr (Calbiochem).

Plasmids, phages and bacterial strains. pNK2 (Kanagawa et al., 1989), a hybrid plasmid consisting of a $2.5 \mathrm{~kb}$ Pst I fragment containing the P-nylB gene and $2.6 \mathrm{~kb}$ of pUC12 vector DNA, was used. M13mp18 and mp19 (Yanisch-Perron et al., 1985) were used as vectors for DNA sequencing. Plasmids pKP1500 (Miki et al., 1987) and pKK 223-3 (Amann et al., 1983), which contain the tac promoter, were used as vectors. E. coli JM 103 [ $\triangle$ (lac-pro) thi-1 str A supE endA sbcB15 hsdR4, $\mathrm{F}^{\prime}$ traD36 proA $A^{+} B^{+}$lacI $^{q}$ lacZAM15) (Messing, 1983) and $\mathrm{KP} 3998\left(\mathrm{~F}^{-}\right.$, hsdS20 $\left(\mathrm{r}_{\mathrm{B}}^{-} \mathrm{m}_{\mathrm{B}}^{-}\right)$ara-14 proA2 lacI ${ }^{q}$ galK2 rpsL2 xyl-5 mtl1 supE44, $\lambda^{-}$) (Miki et al., 1987) were used as the recipients for transformation by M13 phage DNAs.

DNA preparation and electrophoresis. Plasmid DNA was prepared by the alkaline extraction method (Birnboim \& Doly, 1979). M13 singlestranded DNA and double-stranded DNA were prepared from the culture supernatant and pellets of the M13-infected cells as described by Sambrook et al. (1989). Agarose gel electrophoresis of DNA was done by conventional methods (Sambrook et al., 1989). SDS-PAGE of proteins was done by the method of Laemmli (1970).

Nucleotide sequencing. This was done by the dideoxynucleotide chain-termination method (Sanger et al., 1977) using 7-deaza-2'deoxyguanosine triphosphate (Mizusawa et al., 1986) and a sequencing kit (Toyobo Co.).

Enzyme assay. Enzyme activities were quantitatively measured by determining the increase of amino groups by the trinitrobenzene sulphonate (TNBS) method (Kinoshita et al., 1977). Unless otherwise specified, enzyme reactions were done at $30^{\circ} \mathrm{C}$, using $1.5 \mathrm{~mm}-\mathrm{AL} 2$ as substrate (standard assay condition) in $20 \mathrm{~mm}$-potassium phosphate buffer containing $10 \%(\mathrm{v} / \mathrm{v})$ glycerol (pH 7-2) (buffer A) (Kinoshita $e t$ al., 1977). For qualitative detection of the activity of purified enzyme toward various dipeptides, the enzyme $\left(0.3 \mathrm{mg} \mathrm{ml}^{-1}\right)$ was incubated with dipeptides $\left(5 \mathrm{mg} \mathrm{ml}^{-1}\right)$ in buffer $\mathrm{A}$ for $20 \mathrm{~h}$, and reaction products were spotted on to thin-layer silica gel sheets $\left(60 \mathrm{~F}_{254}\right.$, Merck), developed with $n$-propanol/water/ethyl acetate/aqueous ammonia (24:12:4:1, by vol.) and detected with ninhydrin ( $0 \cdot 2 \%$ in $n$-butanol) (Negoro et al., 1983). Proteins were measured from the absorbance at $280 \mathrm{~nm}$. For F-EII, $A_{280} 1 \%$ was taken as 15 (Negoro et al., 1989), and this value was used for the estimation of the P-EII enzyme concentration.

The $\mathrm{pH}$ stability of P-EII was tested by incubating the enzyme $\left(0.3 \mathrm{mg} \mathrm{m}^{-1}\right)$ at $30^{\circ} \mathrm{C}$ for $2 \mathrm{~h}$ in either $50 \mathrm{~mm}$-phosphate buffer

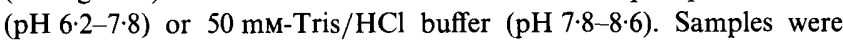
diluted 100 -fold in buffer $\mathrm{A}$ before being assayed.

For the substrate specificity tests (Table 2), to confirm that the enzyme had no detectable activity toward the 6-aminohexanoate-cyclic dimer and $N$-carbobenzoxy-6-aminohexanoate dimer, the purified enzyme $\left(1.7 \mathrm{mg} \mathrm{ml}^{-1}\right)$ was incubated with $10 \mathrm{~mm}$ of these substrates at $30^{\circ} \mathrm{C}$ in buffer $\mathrm{A}$, and the reaction products $(0.3 \mu \mathrm{l})$ were spotted on thin-layer silica gel sheets $\left(60 \mathrm{~F}_{254}\right.$, Merck) developed using $n$ butanol/acetic acid/water $(4: 1: 2$, by vol.). However, no products were detected even after $20 \mathrm{~h}$ of reaction with ninhydrin $(0.2 \%$ in $n$ butanol). However, 6-aminohexanoate was detected after $1 \mathrm{~h}$ of reaction from a reaction mixture containing $10 \mathrm{~mm}$-6-aminohexanoatedimer and the purified enzyme $\left(0.02 \mathrm{mg} \mathrm{ml}^{-1}\right)$.

Enzyme purification. Cell extracts were prepared from parental Pseudomonas sp. NK87 cells grown in 20 litres of CDY medium (Negoro et al., 1980). The cells were disintegrated in a French press $\left(400 \mathrm{~kg} \mathrm{~cm}^{-2}\right)$, and the suspension was centrifuged $(10000 \mathrm{~g})$. The supernatant obtained $(200 \mathrm{ml})$ was used as crude enzyme solution. From the extracts the P-EII enzyme was purified by two passages through a DEAE-Sephadex A50 column, gel filtration chromatography using Toyopearl HW55, DEAE-Toyopearl 650S chromatography, and preparative PAGE. (See Table $1 a$ ).

To purify the P-EII enzyme from $E$. coli KP3998 harbouring pNK3, the cells were cultivated at $37^{\circ} \mathrm{C}$ in 2.4 litres of $\mathrm{LB}$ medium containing $50 \mu \mathrm{g}$ ampicillin $\mathrm{ml}^{-1}$, using a reciprocal shaker. When the culture density reached $3 \times 10^{9} \mathrm{cells} \mathrm{ml}^{-1}$; isopropyl $\beta$-D-thiogalactoside (final concentration, $0.1 \mathrm{~mm}$ ) was added to the culture broth. After a further $2 \mathrm{~h}$ of cultivation, cells (wet weight, $36 \mathrm{~g}$ ) were harvested, washed with 50 mM-potassium phosphate buffer ( $\mathrm{pH} 7 \cdot 2$ ) (buffer B), and suspended in $30 \mathrm{ml}$ buffer B. The cells were disintegrated in the French press $\left(900 \mathrm{~kg} \mathrm{~cm}^{2}\right)$, and the suspension was centrifuged $(10000 \mathrm{~g})$. The supernatant obtained $(49 \mathrm{ml})$ was used as crude enzyme solution. The enzyme precipitated with $30 \%$ saturation of ammonium sulphate was dissolved in $40 \mathrm{ml}$ buffer $\mathrm{A}$, and dialysed against buffer $\mathrm{A}$ for $16 \mathrm{~h}$. The sample $(41 \mathrm{ml})$ was applied to a DEAE-Sepharose CL-6B column $(4.2 \times 34 \mathrm{~cm})$ equilibrated with buffer $A$, and eluted with a linear gradient of $\mathrm{NaCl}(0.05-0.5 \mathrm{M})$ in a total volume of 1.8 litres. The active fractions were concentrated by ultrafiltration (UP-20, Advantech). The sample $(49 \mathrm{ml})$ was applied to a Q-Sepharose column $(2.8 \times 18 \mathrm{~cm})$ equilibrated with buffer $\mathrm{A}$, and eluted with a linear gradient of $\mathrm{NaCl}$ $(0 \cdot 1-0.5 \mathrm{M})$ in a total volume of 1.2 litres. For amino acid analysis and sequencing of the $\mathrm{N}$-terminal region of the enzyme, samples were desalted on a Sephadex G50 column equilibrated with distilled water, and lyophilized (see Table $1 b$ ).

F-EII enzyme which had been purified from E. coli 294(pNL4) previously and stored at $-80^{\circ} \mathrm{C}$ (Negoro et al., 1989) was used for the inhibition experiment (see Fig. 6).

Amino acid composition and $N$-terminal amino acid sequence. The amino acids of the purified enzyme were sequenced by sequential Edman degradation using an automated protein sequencer (Applied Biosystems model 470A). The purified sample was hydrolysed at $110^{\circ} \mathrm{C}$ in $6 \mathrm{M}-\mathrm{HCl}$ containing $0.2 \%$ phenol for $24 \mathrm{~h}$. The amino acid 
(a)

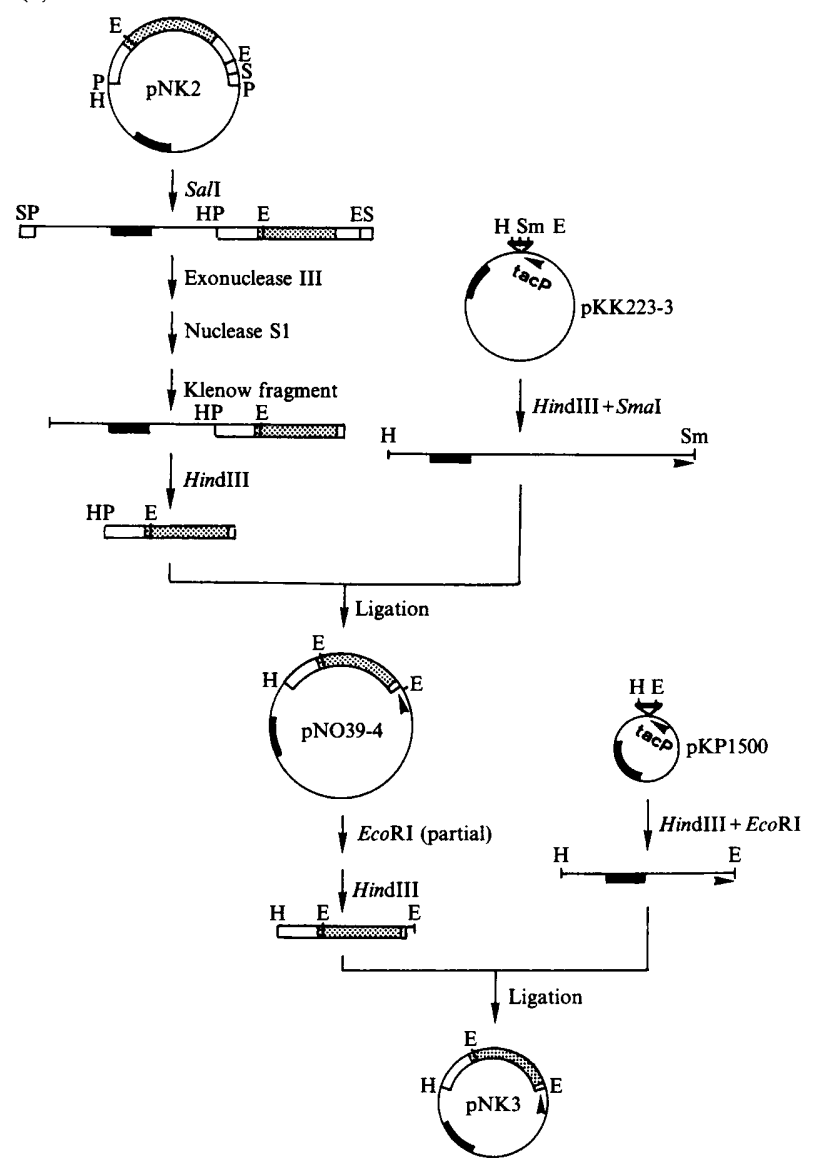

(b)

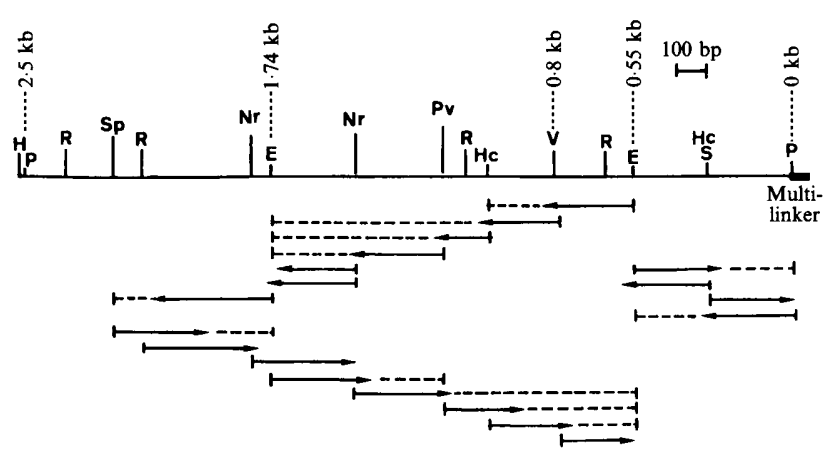

Fig. 1. Construction of plasmid pNK3, which strongly expresses the P$n y l B$ gene $(a)$, and sequencing strategy of the P-nylB gene $(b)$. $(a)$ To eliminate an upstream region of P-nylB included in pNK2, pNK2 was digested with $S a l I$, followed by exonuclease III. The $5^{\prime}$-protruding ends were removed by S1 nuclease treatment and repaired by DNA polymerase (Klenow fragment) treatment. This fragment was digested with HindIII and fractionated by agarose gel electrophoresis. The $2.0 \mathrm{~kb}$ fragment containing P-nylB was recovered and integrated between the HindIII and SmaI sites in a multilinker region of pKK2233. The resulting plasmid was named pNO39-4. pNO39-4 was partially digested with $E c o$ RI, and then completely digested with HindIII, and the $2.0 \mathrm{~kb}$ EcoRI-HindIII fragment was recovered from the agarose gel. This fragment was ligated to pKP1500 which had been digested composition was measured by an amino acid analyser (Hitachi model L8500).

\section{Results}

Sequence of the P-nylB gene

The DNA base sequence of a $2049 \mathrm{bp}$ region containing the P-nylB gene starting from the PstI site in the multilinker region (see Fig. 1) was determined by the dideoxynucleotide chain-termination method. An open reading frame (ORF) of 1188-bp, beginning at ATG (611 bp) and terminating at TAG (1799 bp), and coding for 396 amino acids, was observed (Fig. 2). At 6 bp upstream of the translational initiation codon a consensus Shine-Delgarno sequence of GAGG was observed, and downstream of the termination codon there were two short (5 bp) inverted repeats and one long (13 bp) inverted repeat.

The P-EII enzymes purified from Pseudomonas sp. NK87 and from $E$. coli harbouring pNK 3 containing the P-nylB gene in expression vector pKP1500 (described below) were subjected to Edman degradation in order to determine the amino acid sequence of the $\mathrm{N}$-terminal region. The 10 amino acid sequence of the enzyme from $E$. coli KP3998(pNK3) was identical to the sequence which starts from the expected initiation Met codon. However, for the enzyme derived from Pseudomonas sp. NK87, in addition to the major sequence of Phe-ArgAsp-Pro-(Thr)-Val-Pro-Gly-Asn-Ser-His-Ile-Pro-ArgGln-Asp-, minor sequences of (Pro, Val)-Pro-(Val, Gly)(Pro, Phe, Asn)-(Gly, Arg)-Asp were observed. The major sequence coincides with the sequence from the seventh to twenty-second amino acids deduced from the base sequence. The minor sequences are considered to be a mixture of Val-Pro-X-Phe-Arg-Asp-, Pro-X-Val-ProGly-Asn- and Val-Pro-Gly-Asn- which would have originated from the P-nylB gene product having 3, 9 and 11 amino acids respectively eliminated from its $\mathrm{N}$ -

with EcoRI and HindIII, and treated with bacterial alkaline phosphatase, and then used to transform E. coli KP3998. The transformants were selected and the structure of the plasmid pNK3 harboured in the transformant was confirmed from its restriction map. Inserted fragments are shown as boxes, in which the P-nylB regions are shaded. Vector regions are shown as thin lines, in which ampicillin resistance genes are marked by black boxes. The tac promoter regions are shown as arrowheads. (b) The top line shows the locations of restriction sites in the inserted DNA fragment of pNK2. E, EcoRI; H, HindIII; Hc, HincII ; Nr, NruI ; P, PstI; Pv, PvuII; R, RsaI; S, SalI; Sm, SmaI; Sp, SphI; and V, EcoRV. The horizontal dashed and solid lines below the restriction map represent the DNA fragments subcloned in $\mathrm{M} 13 \mathrm{mp} 18$ or mp19, in which the sequences represented by the solid lines were determined. The direction of sequencing is shown by the arrows. 


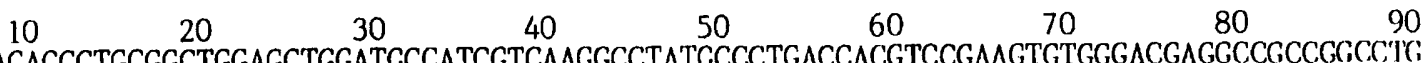
CTCCAGGGAGACCCTCCGCCTGCACCTGGATCCCATCGTCANC,GCCTATCCCCCTCACC,ACGTCOGA V W D E A A G L

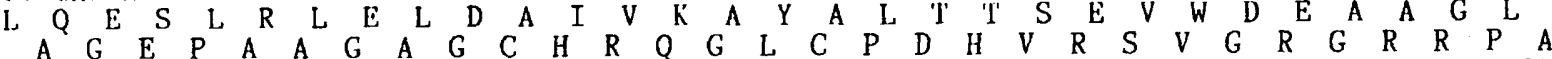

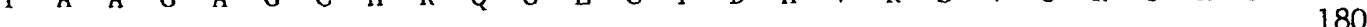
CTGGCGACGACCCGCACCATCTATGTCGTCGGTTTCCAGGCCTCGAAGGGCCTGGCGCTGGATTTCGCCAGCCGCCTGCTCTGGGCGCGT

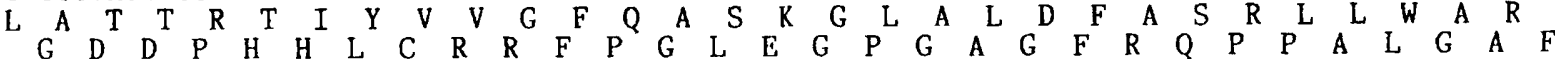
270 $S N$ V I F I D N A S G T F G E I I N A D P R Q S V V V L V D

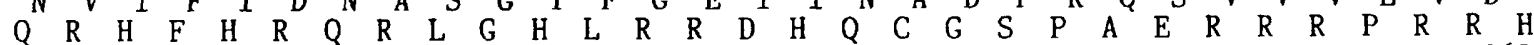
ACCGCCTCCTATGCGACGCGCGGCATCAAGCTGGTGGAGAAGCTGAAGTCGATGGACATGCCGCTGGTCATCGTCACAGACAAGTTCAGC $\begin{array}{llllllllllllllllllllllllllllllll}T & A & S & Y & A & T & R & G & I & K & L & V & E & K & L & K & S & M & D & M & P & L & V & I & V & T & D & K & F & S\end{array}$

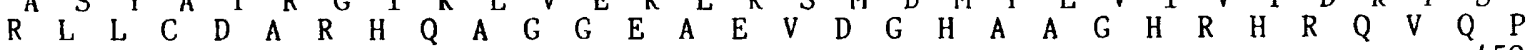

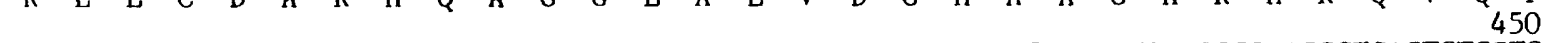
CACTGGGCCTTCGCCTATACGCGCTTCGTATTCGAGCCGCATACGCTTGTAAAAACCTTCTGGGATTCGACGGCGAGCCTCAGTGTCGTC

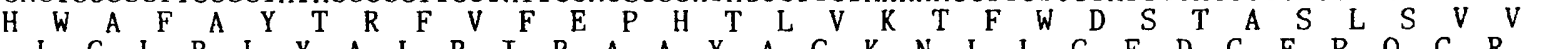
$\begin{array}{llllllllllllllllllllllllllllll}L & G & L & R & L & Y & A & L & R & I & R & A & A & Y & A & C & K & N & L & L & G & F & D & G & E & P & Q & C & R & \Lambda\end{array}$ CTCAACCTGCTGATCGACGCCGTCGCCACCAAGCTCGGGCCGAAGGCCAAGCGCAACTTCGCCATGATGAGCGATATGGGCACCCTCTTC

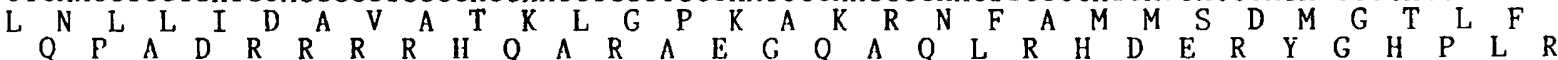

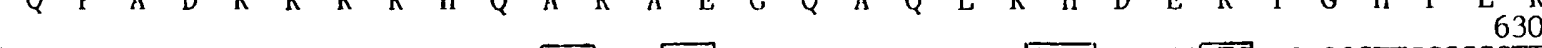

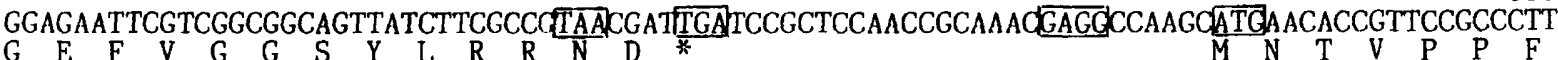

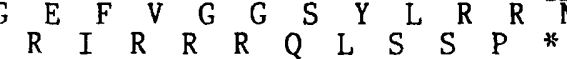

CCGCGATCCGACCGTACCCGGCAATTCCCATATTCCAAGGCAGGATTGGGACCGGGCGCCTGGAATCGCTGGACCTTCCAGCATGTCCO $\begin{array}{llllllllllllllllllllllllllllllll}R & D & P & T & V & P & G & N & S & H & I & P & R & Q & D & W & D & R & A & P & W & N & R & W & T & F & Q & H & V & R\end{array}$ CGAGCTTCTGCCGACCACGAAGGTCTGGCGCGGAACGGGGCCGGCAAGCCCTCTGCCGGTCGATCTGCGGGATATCGATGCCGTTTCCTT

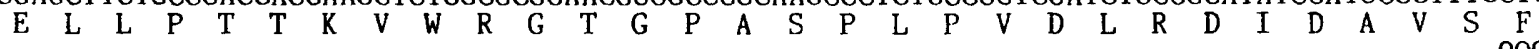
CGCGGCGGAGGGGCAGAGCCATACCATCGCCGGCTTCCTCGAAACGAGCTATGCCGATGGCTTCCTGGTGCTCCACGGCGGAAAGATCGT

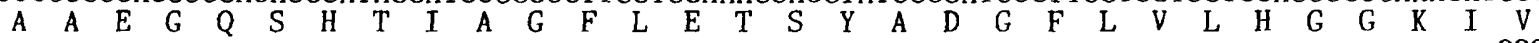
GGCCGAGCGCTACCTCAACGGAATGGCGCCGCACACCCAGCACCTGTCGCAATCGGTCGCCAAATCGGTCGTCGGCACCGTGGCGGGCAT

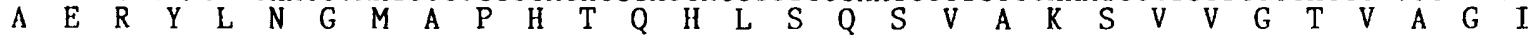
CCTGATCGATCGCGGCGTGGTCAACCCCGCCGCGCTCCTGACGCACTACCTTCCGGAACTGGAGGCGACAGCCTATCGCGGCGCGACCGT $\begin{array}{lllllllllllllllllllllllllllllllll}\mathrm{L} & \mathrm{I} & \mathrm{D} & \mathrm{R} & \mathrm{G} & \mathrm{V} & \mathrm{V} & \mathrm{N} & \mathrm{P} & \mathrm{A} & \mathrm{A} & \mathrm{L} & \mathrm{L} & \mathrm{T} & \mathrm{H} & \mathrm{Y} & \mathrm{L} & \mathrm{P} & \mathrm{E} & \mathrm{L} & \mathrm{E} & \mathrm{A} & \mathrm{T} & \mathrm{A} & \mathrm{Y} & \mathrm{R} & \mathrm{G} & \mathrm{A} & \mathrm{T} & \mathrm{V}\end{array}$ CCAGCACGTACTCGACATGACCAGCGGCGTGGTCTTCGACGAGACCTATACCGCGCTCGATTCCCACATGGCGCAGCTGGATGTCGCCAG $\begin{array}{llllllllllllllllllllllllllllll}Q & H & V & L & D & M & T & S & G & V & V & F & D & E & T & Y & T & A & L & D & S & H & M & A & Q & \text { L } & \text { D } & \text { V } & \text { A } & \text { S }\end{array}$ CGGCTGGAAGGATAGCCCGAACCCGGACTGGCCCACGCATGTCTGGGATCTGATCCTGTCCCTGAAGGATCTGGAATGCCCGCACGGCGC

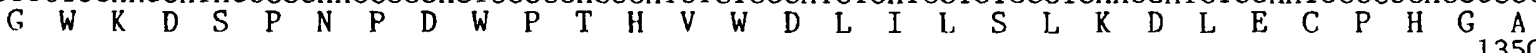
CTCCTTCCGCTATCGCTCGATCGAGACCGATGTGCTGGCCTTCGTGCTGCAACGCGCCGCCGCCGCGCCGCTTGCGGAACTCGTCAGCCG

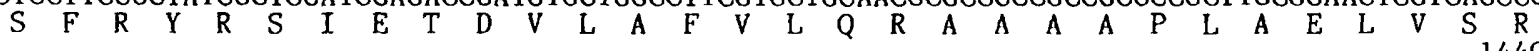
CGAATTGTGGGCGCCGATGGGGGCGGAGGAAGACGCCTATTTCACCGTGGATACCGCCGGCTATGCGCTGGGTGACGGCGGGTTCAACGC

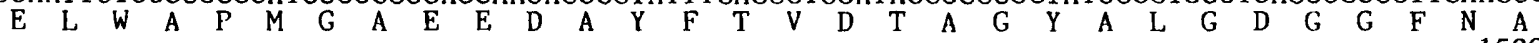
GACCCTTCGCGACTATGCGCGTTTCGCCTTGCTGCATCTTCGCGGCGGCGAGATCGATGGCCGGCGTATCGTGTCGCCCGGCTGGATTGC

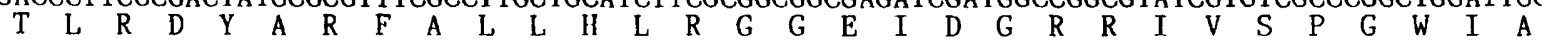
CGCAACGCGCTTCGGTGCCGATCCGGCGCTCTTCGGCGACATTTATCGAGAGGCCCTGCCCGCCGGCGCTATCACAACCAGTTCTGGAT $\begin{array}{lllllllllllllllllllllllllllllll}\text { A } & \text { T } & \text { R } & \text { F } & \text { G } & \text { A } & \text { D } & \text { P } & \text { A } & \text { L } & \text { F } & \text { G } & \text { D } & \text { I } & \text { Y } & \text { R } & \text { E } & \text { A } & \text { L } & \text { P } & \text { A } & \text { G } & \text { A } & \text { Y } & \text { H } & \text { N } & \text { Q } & \text { F } & \text { W } & \text { I }\end{array}$ CGAGGATACCGCACGCGGCGCCTATATGGCGCGCGGCGTCTTCGGACAACTGATCTACATCGACCCGGAAGCGGATTTCGCGGCGGTCAT

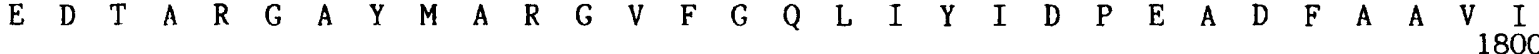
CCTGTCGAGCTGGCCGGAATTCGTGAGCACGACGCGGCTGCGGACGGCGCTTGCGGCGGTCAGGGCCGTTCGCGAGGCGCTGTCAGCGTA

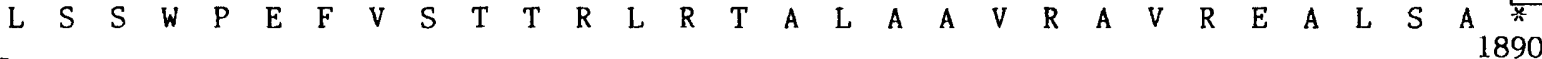
GCCAGCGGGCGATTCACCGCTTTGTGCGGGATAGCCCCGGCGCAGGCCAAAGCGCCAAACACAAAAAGAGAGCATTTCCGGCGAACCCGT GTTCACCGGAAATGTTCAAGTCGGATCACACTCACGCGACCTCCATCCAACCCGCACGAAAACGCAATACTCCGCACGTAGCGTCCCTCG GAAACCCATGCCGGCCGCAAGCCGGCTCAAACAAGGATGACCGCGTGACGGCAACATTTCCAGGACGCC

Fig. 2. 
terminus. Although it is possible that this non-uniformity of the $\mathrm{N}$-termini is due to artifacts occurring during the purification processes, it may also mean that the P-nylB gene product is processed in several different ways in $P$ seudomonas sp. NK87. Since the P-EII enzyme from $E$. coli KP3998(pNK3) has slightly higher specific activity toward 6-aminohexanoate-dimer than the enzyme from strain NK87 (described below), the processing in the Pseudomonas strain seems not to be essential for maturation of the protein but rather to be due to partial degradation by endogenous proteases.

The number of amino acid residues per subunit predicted from this ORF agreed well with that calculated from the results of amino acid analysis of the purified protein from E. coli KP3998(pNK3) (numbers in parentheses) except for unstable amino acids such as Trp: Lys, 5 (6.0); His, 13 (13.3); Trp, 11 (0); Arg, 27 (27.5); Asp + Asn, 35 (35.6); Thr, 26 (25.8); Ser, 21 (20.4); Glu + Gln, 29 (32.0); Pro, 24 (23.0); Gly, 31 (30.3); Ala, 53 (54.6); Cys, 1 (0); Val, 30 (30.9); Met, 6 (5.9); Ile, 16 (15.9); Leu 38 (39.6); Tyr, 13 (13.0); Phe, 17 $(17 \cdot 2)$. From these results, we concluded that this ORF encodes P-EII enzyme.

Alignment of the nucleotide sequences of the P-nylB and F-nylB genes by the method of Wirbur \& Lipman (1983) showed that these genes have $53 \%$ sequence similarity in the coding region. This similarity is less than that observed for the P-nylA and F-nylA (99\%) (Tsuchiya et al., 1989). Alignment of the amino acid sequences by the method of Dayhoff et al. (1978) revealed that the sequence similarity between the P-EII and F-EII enzymes is $35 \%$ including gaps (Fig. 3). This value is much less than that between P-EI and F-EI (99\%) (Tsuchiya et al., 1989).

\section{Purification of P-EII}

P-EII was initially purified from a 20 litre culture of Pseudomonas sp. NK87 (Table 1a), but the amount of the enzyme was insufficient for characterization of the enzyme. Therefore, we constructed plasmid pNK3 in which the P-nylB gene (Kanagawa et al., 1989) was integrated into the $E$. coli expression vector pKP1500 (Fig. $1 a$ ). The P-EII enzyme was purified 25 -fold from $E$. coli KP3998(pNK3) at a yield of $19 \%$ (Table $1 b$ ). The

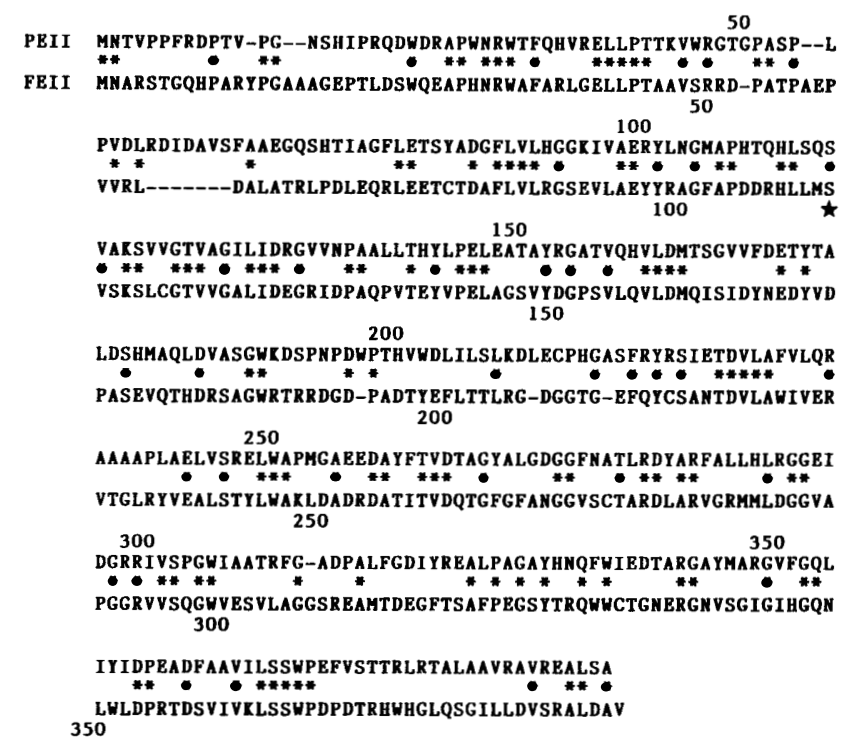

Fig. 3. Sequence alignment of P-EII and F-EII. Amino acids are shown in one-letter code. The sequences are numbered from the $\mathrm{N}$-termini. Alignment of the sequences was done by the method of Dayhoff et al. (1978). Identical amino acids between P-EII and F-EII are marked by asterisks. The active-site serine of F-EII enzyme (Ser112) is marked by a star.

final specific activity of the enzyme from the $E$. coli clone $\left[4 \cdot 0 \mu \mathrm{mol} \mathrm{min}^{-1} \mathrm{mg}^{-1}\left(\mathrm{U} \mathrm{mg}^{-1}\right)\right]$ was slightly higher than that from parental strain NK87 $\left(2.7 \mathrm{U} \mathrm{mg}^{-1}\right)$ (Table 1). The enzyme from E. coli clone was judged to be homogeneous, yielding a single protein band on SDSPAGE (Fig. 4). This enzyme preparation was used for characterization of the P-EII enzyme.

\section{Characterization of P-EII and comparison with F-EII}

The $M_{\mathrm{r}}$ of P-EII was estimated to be 76000 by HPLC using a TSK-GEL G3000SW column. The $M_{\mathrm{r}}$ of the subunit of the P-EII enzyme estimated by SDS-PAGE was 42000 . This value agrees well with that calculated for the ORF of the P-nylB gene $\left(M_{\mathrm{r}} 43383\right)$ (Fig. 2). From these results, P-EII was estimated to be a homodimer enzyme like F-EII (Kinoshita et al., 1981).

The purified P-EII enzyme had nearly equal activities against various oligomers of 6-aminohexanoate, from the dimer to the pentamer (AL2-AL5) (Table 2). It had no significant activities against 56 different dipeptides (see Methods). When AL4 was used as a substrate for the

Fig. 2. Nucleotide sequence of P-nylB and deduced amino acid sequence of P-EII. The predicted amino acid sequence of the PEII enzyme, which starts from position 611 (frame 2) is indicated below the nucleotide sequence in one-letter code. Putative translational initiation and termination codons and a putative ribosome-binding site (Shine-Dalgarno sequence) are boxed. Amino acid sequences of two unknown ORFs (frames 1 and 3) located upstream of the P-nylB gene are also shown. Palindromic sequences are indicated by arrows. 
Table 1. Purification of P-EII from (a) Pseudomonas sp. NK87 and (b) E. coli KP3998(pNK3)

\begin{tabular}{lccccc}
\hline \hline $\begin{array}{l}\text { Purification } \\
\text { step }\end{array}$ & $\begin{array}{c}\text { Protein } \\
(\mathrm{mg})\end{array}$ & $\begin{array}{c}\text { Activity } \\
(\mathrm{U})\end{array}$ & $\begin{array}{c}\text { Sp. act. } \\
\left(\mathrm{U} \mathrm{mg} \mathrm{mg}^{-1}\right)\end{array}$ & $\begin{array}{c}\text { Yield } \\
(\%)\end{array}$ & $\begin{array}{c}\text { Purification } \\
(\text {-fold })\end{array}$ \\
\hline $\begin{array}{l}(a) \\
\text { Crude extract }\end{array}$ & 14000 & 167 & $0 \cdot 0058$ & 100 & 1 \\
DEAE-Sephadex A-50 (1st) & 1580 & $75 \cdot 9$ & $0 \cdot 048$ & 45 & $8 \cdot 2$ \\
DEAE-Sephadex A-50 (2nd) & 175 & $50 \cdot 8$ & $0 \cdot 29$ & 30 & 50 \\
Toyopearl HW55 & $94 \cdot 9$ & $41 \cdot 1$ & $0 \cdot 43$ & $24 \cdot 5$ & 75 \\
DEAE-Toyopearl 650S & $38 \cdot 0$ & $25 \cdot 1$ & $0 \cdot 66$ & $15 \cdot 1$ & 114 \\
Preparative electrophoresis & $1 \cdot 5$ & $4 \cdot 2$ & $2 \cdot 7$ & $2 \cdot 5$ & 460 \\
(b) & & & & & \\
Cell extract & 5100 & 790 & $0 \cdot 16$ & 100 & 1 \\
Ammonium sulphate & 420 & 560 & $1 \cdot 3$ & 71 & $8 \cdot 6$ \\
precipitation & 150 & 420 & $2 \cdot 8$ & 54 & 18 \\
DEAE-Sepharose CL-6B & 37 & 150 & $4 \cdot 0$ & 19 & 25 \\
Q-Sepharose & & & & & \\
\hline \hline
\end{tabular}

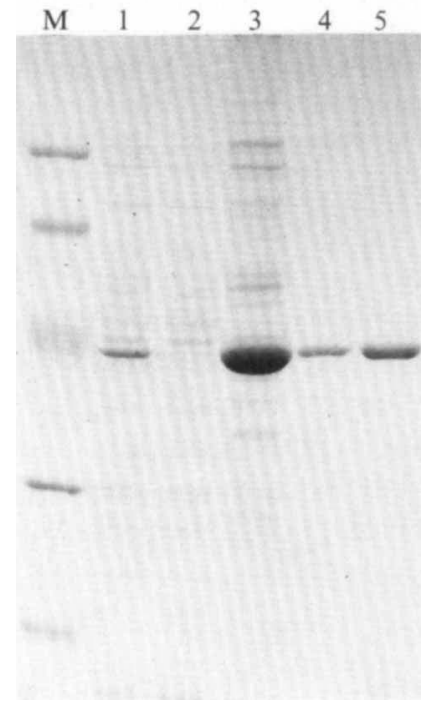

Fig. 4. SDS-PAGE of P-EII enzyme from E. coli KP3998(pNK3) at each purification stage. Lane $\mathrm{M}, M_{\mathrm{r}}$ markers [from the top, phosphorylase $b(94000)$, bovine serum albumin (67000), ovalbumin $(43000)$, carbonic anhydrase (30000) and soybean trypsin inhibitor (20100); lane 1, cell extract of E. coli KP3998(pNK3); lane 2, supernatant fraction after precipitation with ammonium sulphate (30\% saturated); lane 3 , fraction of cell extract precipitated by ammonium sulphate ( $30 \%$ saturated); lane 4 , partially purified P-EII after DEAE-Sepharose CL-6B column chromatography; lane 5, purified P-EII after Q-Sepharose Fast Flow chromatography.

P-EII enzyme, 6-aminohexanoate and AL3 were produced as major products, and AL3 was subsequently subjected to hydrolysis (Fig. 5). Moreover, the enzyme had no significant activity toward Z-AL2 (Table 2). These results suggest that the P-EII enzyme digests linear oligomers of 6-aminohexanoate exogenously from the amino-terminus as a monomeric unit. This characteristic
Table 2. Substrate specificity of P-EII

Enzyme assays were done at $30^{\circ} \mathrm{C}$ in buffer A containing $1.5 \mathrm{~mm}$ of each substrate (see Methods for details).

\begin{tabular}{llc}
\hline \hline Substrate & & $\begin{array}{c}\text { Relative activity } \\
(\%)\end{array}$ \\
\hline 6-Aminohexanoate-dimer & (AL2) & 100 \\
6-Aminohexanoate-trimer & (AL3) & 98 \\
6-Aminohexanoate-tetramer & (AL4) & 115 \\
6-Aminohexanoate-pentamer & (AL5) & 82 \\
6-Aminohexanoate-cyclic dimer & (AC2) & $<0 \cdot 1$ \\
$N$-Carbobenzoxy-6- & (Z-AL2) & $<0 \cdot 1$ \\
aminohexanoate-dimer & & \\
\hline \hline
\end{tabular}

is similar to that defined for the F-EII enzyme (Kinoshita et al., 1981).

Initial rates of the enzyme reaction were measured at $30^{\circ} \mathrm{C}$ by using various concentrations of AL2 (0.2$2.0 \mathrm{mM}$ ). From the Lineweaver-Burk plot, the $K_{\mathrm{m}}$ was estimated to be $0.6 \mathrm{~mm}$; the $k_{\text {cat }}$ obtained by using the $M_{\mathrm{r}}$ of the native enzyme of 84000 was $9 \cdot 2 \mathrm{~s}^{-1}$. The $K_{\mathrm{m}}$ and $k_{\text {cat }}$ values of the F-EII enzyme were $15 \mathrm{~mm}$ and $19 \mathrm{~s}^{-1}$, respectively (Fujiyama et al., 1991). These results indicate that the P-EII enzyme has a higher affinity for AL2 than does the F-EII enzyme.

The optimum $\mathrm{pH}$ for the hydrolysis of AL2 was 7.5. The enzyme was stable only at around neutral $\mathrm{pH}$ (between $\mathrm{pH} 6.8$ and 8.5 ). The optimal temperature for hydrolase activity was $48^{\circ} \mathrm{C}$ in the $10 \mathrm{~min}$ of the enzyme reaction. To examine the thermostability of the enzyme, the enzyme in buffer A was incubated at various temperatures for $30 \mathrm{~min}$, then the residual activities were assayed at $30^{\circ} \mathrm{C}$ and compared with the untreated sample. The enzyme was stable up to $45^{\circ} \mathrm{C}$. 


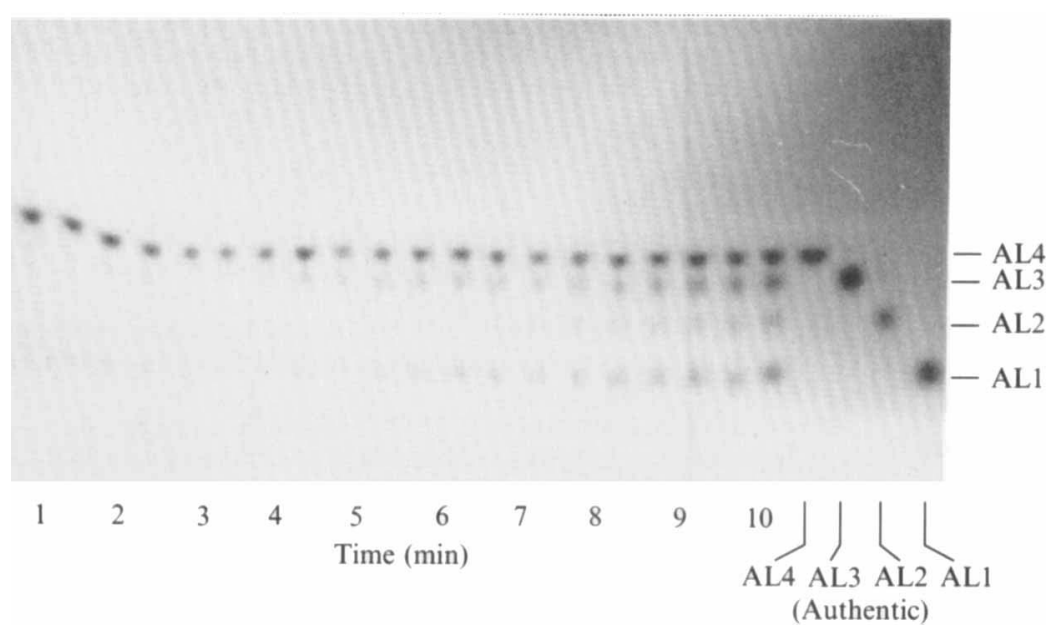

Fig. 5. Thin-layer chromatography for detection of hydrolysates from 6-aminohexanoate-tetramer (AL4) by P-EII enzyme reaction. The P-EII enzyme from $E$. coli KP3998(pNK3) (at the stage of Q-Sepharose Fast Flow chromatography) $\left(78 \mu \mathrm{g} \mathrm{ml}^{-1}\right.$ ) was incubated at $30^{\circ} \mathrm{C}$ with $10 \mathrm{~mm}$ 6-aminohexanoate tetramer in buffer A. Aliquots $(0 \cdot 3 \mu \mathrm{l})$ of the reaction mixture were sequentially spotted on the thin-layer plate at the time shown below the plate, and developed with $n$-propanol/water/ethyl acetate/aqueous ammonia (24:12:4:1, by vol.) Reaction products were detected with ninhydrin. AL1, AL2, AL3 and AL4 indicate authentic 6-aminohexanoate, 6aminohexanoate-dimer, -trimer and -tetramer, respectively.

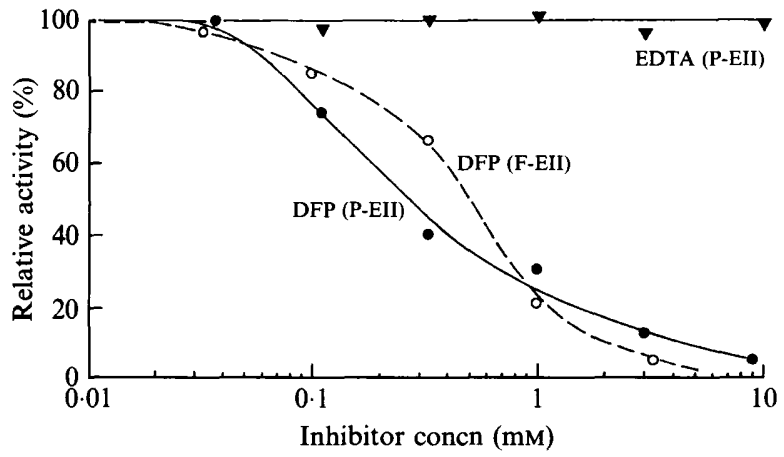

Fig. 6. Inhibition of EII activity by DFP and EDTA. The purified EII enzymes $(0.1 \mathrm{ml})\left(78 \mu \mathrm{g} \mathrm{ml}^{-1}\right.$ for P-EII, $0.63 \mathrm{mg} \mathrm{ml}^{-1}$ for F-EII) were mixed with an inhibitor $(0.1 \mathrm{ml})$, and the mixtures were preincubated at $30^{\circ} \mathrm{C}$ for $1 \mathrm{~h}$ before the enzyme assay. Activity was expressed as a percentage of the activity without an inhibitor.

Table 3. Comparison of F-EII and P-EII

\begin{tabular}{lcc}
\hline Characteristic & F-EII* & P-EII \\
\hline$M_{\mathrm{r}}$ & $\begin{array}{c}42000 \\
\text { (dimer) }\end{array}$ & $\begin{array}{c}42000 \\
\text { (dimer) }\end{array}$ \\
Encoded on & pOAD2 & pNAD6 \\
$\left.K_{\mathrm{m}}\right\}$ (towards AL2) & $15 \mathrm{mM}$ & $0 \cdot 6 \mathrm{~mm}$ \\
$k_{\text {cat }}$ & $19 \mathrm{~s}^{-1}$ & $9 \cdot 2 \mathrm{~s}^{-1}$ \\
Optimum pH & $9 \cdot 0$ & $7 \cdot 5$ \\
Optimum temp. & $40^{\circ} \mathrm{C}$ & $48^{\circ} \mathrm{C}$ \\
\hline \hline
\end{tabular}

* The results for the F-EII enzyme were described previously (Kinoshita et al., 1981; Fujiyama et al., 1991).

The addition of $10 \mathrm{~mm}$-EDTA to the reaction mixture had no effect on the enzyme activity (Fig. 6), suggesting that the enzyme does not require divalent cations. Addition of $1 \mathrm{~mm}$-diisopropyl fluorophosphate (DFP), however, inhibited approximately $80 \%$ of the initial activity, implying that a serine residue plays an important role in the catalytic function of the enzyme. Similar results were observed for the F-EII enzyme (Kinoshita $e t$ al., 1981) (Negoro et al., 1989). Basic characteristics of the P-EII and F-EII enzymes are summarized in Table 3.

\section{Discussion}

The F-nylB and P-nylB genes possessed $35 \%$ similarity (after alignment and insertion of gaps into both sequences) with respect to the amino acid sequences in the whole coding regions. This suggests that these genes have diverged from a common antecedent. The F-EII and P-EII enzymes exhibited similar basic enzymic characteristics; for example, their activities showed similar DFP inhibition profiles (Fig. 6). We have previously shown that radioactive DFP specifically binds to Ser-112 among 26 Ser residues in the F-EII enzyme and that changing Ser-112 to Ala by site-directed mutagenesis resulted in a drastic decrease of the enzyme activity to the detection threshold (Negoro et al., 1989). These results suggest that one of the active-site residues of the F-EII is Ser-112.

The amino acid corresponding to Ser-112 in the F-EII enzyme is aligned with Ser-115 in the P-EII enzyme (Fig. 3). However, Ser-112 of F-EII is coded by AGC (Okada et al., 1983), while Ser-115 of P-EII is coded by TCG (Fig. 2). When an AGY-type Ser codon $(Y=T, C)$ is changed to a TCN-type Ser codon $(\mathrm{N}=\mathrm{A}, \mathrm{G}, \mathrm{C}, \mathrm{T})$, or a TCN codon is changed to an AGY codon, intermediate codons such as TGG (Trp), TGY (Cys) or ACN (Thr) would be generated, in which a single nucleotide substitution occurred at the first or second base in the Ser codons. Although the possibility remains that the conversion of the AGY to TCN codons occurred in one 
step by error-prone repair (Echols \& Goodman, 1991), an alternative explanation is that the Ser residues in at least either one of the EII enzymes were not conserved constantly through evolution. Thus the Ser might be changed once to other amino acids by a single base replacement in the codon and then the altered amino acids would be returned to Ser by a successive base replacement, if the smallest number of the base substitutions occurred in the codon. If this were the case, the following two possibilities could be speculated : (i) microorganisms possess some mechanisms to maintain genes whose products are useless, even if the function of the gene product is lost; (ii) Ser-112 of the F-EII enzyme and Ser-115 of the P-EII enzyme were not involved in enzyme activity. Further study to identify the active-site residue in the EII enzymes is required.

Analysis of the upstream portion of the P-EII coding region revealed that there are two ORFs which start from the 5'-proximal unsequenced region of the P-nylB gene and end at $18 \mathrm{bp}$ upstream (frame 1) or $25 \mathrm{bp}$ upstream (frame 3 ) of the putative Shine-Dalgarno sequence of P-nylB (Fig. 2). The ORF in frame 1 is expected to be efficiently expressed in Pseudomonas cells, since its codon usage agreed well with the codon preference of Pseudomonas strains. The F-nylB gene borne on pOAD2 of Flavobacterium strain KI72 is expressed from a promoter located $6 \mathrm{~kb}$ upstream of the gene in E. coli (Okazaki et al., 1988; Zhou et al., 1990). These results suggest that the P-nylB gene might be expressed as a part of an operon, although the possibility remains that the P-nylB gene has its own promoter.

No significant sequence similarity was observed between the F-EI and F-EII enzymes or between the F-EI and P-EII enzymes. This suggests that the nylA family and $n y l B$ family evolved independently. In contrast, alignment of the F-EII and P-EII sequences has shown that the similarities are $53 \%$ in the nucleotide sequence and $35 \%$ in the amino acid sequence. These values are much lower than those observed for the F-EI and P-EI sequences $(99 \%)$. This suggests that the two nylB genes diverged from their common antecedent much less recently than the nylA genes diverged from each other.

EI and EII catalyse reactions in the sequential pathways for metabolism of 6-aminohexanoate-cyclic dimer. It is reasonable to assume that an ancestral $n y l B$ gene, which encoded an enzyme reaction closer to the central metabolic pathways than the $n y l A$ gene, may have spread among micro-organisms earlier on during the evolutionary process. While the ancestral $n y l B$ gene has evolved to give the present F-nylB and P-nylB genes, micro-organisms having enzyme activities against 6aminohexanoate-dimer seem to have acquired the new ability for cyclic-dimer metabolism by incorporating a more recently evolved nylA gene.
We thank Dr T. Fujio and Dr K. Yamaguchi (Kyowa Hakko Co. Ltd.) for determining the N-terminal amino acid sequence of the P-EII enzyme, and Dr Sakiyama (Osaka University) for amino acid analysis.

\section{References}

Amann, E., Brosius, J. \& Ptashne, M. (1983). Vectors bearing a hybrid trp-lac promoter useful for regulated expression of cloned genes in Escherichia coli. Gene 25, 167-178.

BirnboIM, H. C. \& Doly, J. (1979). A rapid alkaline extraction procedure for screening recombinant plasmid DNA. Nucleic Acids Research 7, 1513-1523.

Cork, D. J. \& KRUEGer, J. P. (1991). Microbial transformations of herbicides and pesticides. Advances in Applied Microbiology 36, 1-66.

DaYhoff, M. O., Schwartz, R. M. \& OrCuTt, B. (1978). A model of evolutionary change in proteins. In Atlas of Protein Sequence and Structure, vol. 5, suppl. 3, pp. 345-352. Edited by M. O. Dayhoff. Washington, DC: National Biochemical Research Foundation.

Echols, H. \& Goodman, M. F. (1991). Fidelity mechanisms in DNA replication. Annual Review of Biochemistry 60, 477-511.

Fujiyama, K., Zhang, Y. Z., Negoro, S., Urabe, I. \& OKada, H. (1991). Characterization of hybrid enzymes between 6-aminohexanoate-dimer hydrolase and its analogous protein. Journal of Fermentation and Bioengineering 71, 298-302.

Hicks, R. J., Stotzky, G. \& Voris, P. V. (1990). Review and evaluation of the effects of xenobiotic chemicals on microorganisms in soil. Advances in Applied Microbiology 35, 195-253.

Kanagawa, K., Negoro, S., Takada, N. \& Okada, H. (1989). Plasmid dependence of Pseudomonas sp. strain NK87 enzymes that degrade 6-aminohexanoate-cyclic dimer. Journal of Bacteriology 171, 31813186.

Kinoshita, S., Kageyama, S., Iba, K., Yamada, Y. \& OKada, H. (1975). Utilization of a cyclic dimer and linear oligomers of $\varepsilon$ aminocaproic acid by Achromobacter guttatus KI72. Agricultural and Biological Chemistry 39, 1219-1223.

Kinoshita, S., Negoro, S., Muramatsu, M., Bisaria, V. S., Sawada, S. \& OKaDA, H. (1977). 6-Aminohexanoic acid cyclic dimer hydrolase: a new cyclic amide hydrolase produced by Achromobacter guttatus KI72. European Journal of Biochemistry 80, 489-495.

Kinoshita, S., Terada, T., Taniguchi, T., Takene, Y., Masuda, S., Matsunaga, N. \& Okada, H. (1981). Purification and characterization of 6-aminohexanoic acid oligomer hydrolase of Flavobacterium sp. KI72. European Journal of Biochemistry 116, 547-551.

LAEMMLI, U. K. (1970). Cleavage of structural proteins during the assembly of the head of bacteriophage T4. Nature, London 227 , 680-685.

Messing, J. (1983). New M13 vectors for cloning. Methods in Enzymology 101, 20-78.

Miki, T., Yasukochi, T., Nagatani, H., Furuno, M., Orita, T., Yamada, H., Imoto, T. \& HoRIUChI, T. (1987). Construction of a plasmid vector for the regulatable high level expression of eukaryotic genes in Escherichia coli: an application to overproduction of chicken lysozyme. Protein Engineering 1, 327-332.

Mizusawa, S., Nishimura, S. \& Seela, F. (1986). Improvement of the dideoxy chain termination method of DNA sequencing by use of deoxy-7-deazaguanosine triphosphate in place of dGTP. Nucleic Acids Research 14, 1319-1324.

Negoro, S., Shinagawa, H., Nakata, A., Kinoshita, S., Hatozaki, T. \& OKADA, H. (1980). Plasmid control of 6-aminohexanoic acid cyclic dimer degradation enzymes of Flavobacterium sp. KI72. Journal of Bacteriology 143, 238-245.

Negoro, S., Taniguchi, T. Kanaoka, M., Kimura, H. \& OKada, H. (1983). Plasmid-determined enzymatic degradation of nylon oligomers. Journal of Bacteriology 155, 22-31.

Negoro, S., Mitamura, T., OKa, K., Kanagawa, K. \& Okada, H. (1989). Determination of the active-site serine of 6-aminohexanoatedimer hydrolase. European Journal of Biochemistry 185, 521-524.

Okada, H., Negoro, S., Kimura, H. \& NaKamura, S. (1983). Evolutionary adaptation of plasmid-encoded enzymes for degrading nylon oligomers. Nature, London 306, 203-206. 
Okazaki, M., Uemura, T., Nishimori, Y., Wakamatsu, K., ShimoSaKa, M., Saito, H., Negoro, S. \& OKada, H. (1988). Analysis of a promoter-like region in Flavobacterium which controls 6-aminohexanoic acid linear oligomer hydrolase gene expression in Escherichia coli. Journal of Fermentation Technology 66, 489-494.

SambrooK, J., Fritsch, E. F. \& Maniatis, T. (1989). Molecular Cloning: a Laboratory Manual, 2nd edn. Cold Spring Harbor, New York: Cold Spring Harbor Laboratory.

SANGER, F., Nicklen, S. \& Coulson, A. R. (1977). DNA sequencing with chain-terminating inhibitors. Proceedings of the National Academy of Sciences of the United States of America 74, 5463-5467. Tsuchiya, K., Fukuyama, S., Kanzaki, N., Kanagawa, K., Negoro, S. \& OKaDA, H. (1989). High homology between 6-aminohexanoate- cyclic-dimer hydrolases of Flavobacterium and Pseudomonas strains. Journal of Bacteriology 171, 3187-3191.

WIRBUR, W. J. \& LIPMAN, D. J. (1983). Rapid similarity searches of nucleic acid and protein data banks. Proceedings of the National Academy of Sciences of the United States of America 80, 726-730.

Yanisch-Perron, C., VieIRA, J. \& Messing, J. (1985). Improved M13 phage cloning vectors and host strains: nucleotide sequences of the M13mp18 and pUC19 vectors. Gene 33, 103-119.

Zhou, Z. E., Nishimori, Y., Shimosaka, M. \& Okazaki, M. (1990). Transcription of a gene for 6-aminohexanoic acid linear oligomer hydrolase of Flavobacterium sp. KI72 in Escherichia coli. Journal of Fermentation and Bioengineering 70, 266-268. 